\title{
Negociando o Destino dos Embriões Humanos Produzidos na Reprodução Assistida: \\ Criopreservação, descarte, doação e seus agenciamentos em uma clínica de Porto Alegre ${ }^{1}$
}

Débora Allebrandt*

\section{Resumo}

Conforme a Lei 11.105/2005, a pesquisa com embriões é permitida no Brasil. Cabe à ANVISA controlar o número e o destino de embriões produzidos através do SisEmbrio, um banco de dados que controla a manipulação dos tecidos germinativos em todo o país. Para tanto, centros de RA devem enviar um relatório anual e confirmar o estado legal daqueles embriões que foram armazenados em seus tanques de nitrogênio. Esse artigo baseia-se na pesquisa etnográfica realizada junto a uma clínica de reprodução assistida localizada na cidade de Porto Alegre. Durante a pesquisa, pude acompanhar as práticas que culminaram na elaboração deste relatório. Trata-se de um ritual de ligações, TCLEs e assinaturas entre a clínica e as pessoas que contrataram serviços de criopreservação. Negocia-se o destino de seu material biológico. Tomo esse agenciamento como a construção de conhecimento sobre embriões e sua transição entre tecidos(descartáveis)/vida potencial (a ser preservada). Tal percepção assinala interseccionalidades na produção e gestão da política de ciência, responsabilidade e ética do uso e destino de embriões.

\section{Palavras-chave}

Doação de embriões. SisEmbrio. Reprodução Assistida.

\begin{abstract}
According to Law 11,105 / 2005, embryo research is permitted in Brazil. It is up to ANVISA to control the number and destiny of embryos produced through SisEmbrio. SisEmbrio is a database that controls the manipulation of ova tissue throughout the country. To do so, AR
\end{abstract}

\footnotetext{
${ }^{1}$ Agradeço a meus interlocutores na clínica de reprodução assistida pela confiança em mim depositada e ao financiamento dessa pesquisa através da bolsa de pós-doutorado júnior (PDJ) concedida pelo CNPq de dezembro de 2013 a novembro de 2014 e da Bolsa Jacques Gutwirth - CAPES, de dezembro de 2014 a março de 2015.

*Débora Allebrandt é professora do Programa de Pós-Graduação em Antropologia Social da Universidade Federal de Alagoas (UFAL). E-mail: debora.allebrandt@ics.ufal.br.
} 
centers must send an annual report and confirm the legal status of those embryos that have been stored in their nitrogen tanks. This paper is based on an ethnographical research in a AR centrer in Porto Alegre - Brazil. During the reasearch I was abble to witness the practices that made possible the elaboration of SisEmbio's report. For its elaboration, there is a ritual of connections, TCLEs and signatures between the clinic and the people who contracted cryopreservation services. The fate of the biological material is negotiated. I take this agencies as a construction of knowledge about embryos and their transition between tissues (disposable) / potential life (to be preserved). Such perception points to intersectionality in the production and management of science policy, responsibility and ethics of the use and destination of embryos.

\section{Keywords}

Embryo donation. SisEmbrio. Assisted Reproduction (AR).

\section{Introdução}

A produção, manipulação, preservação e descarte de embriões nunca foi um terreno tranquilo na reprodução assistida. Debates em torno da viabilidade e potencial de vida dos embriões foram pautados dentro de círculos especializados e, em alguns contextos, tornaram-se também o ponto nevrálgico das preocupações éticas da população leiga. Este artigo busca contextualizar, a partir da experiência de pesquisa de campo, os diversos agenciamentos que situam os embriões ora como uma substância resultado de um grande investimento financeiro e emocional, ora como algo "descartável" ou dispensável. A discussão apresentada aqui será conduzida a partir de uma breve revisão histórica da fertilização in vitro e como se configurou ao longo de seu desenvolvimento a existência de embriões extranumerários. Em seguida, exploraremos dos dados da produção e criopreservação de embriões no Brasil, comparando-os com os de outros países e suas decisões quanto à viabilidade de realização de pesquisas com embriões. Tomamos a negociação dos destinos possíveis dos embriões a partir de uma abordagem etnográfica que leva em consideração o fator temporal para a elaboração da viabilidade dos embriões e do projeto parental neles inscrito. Nesse sentido, a negociação do destino dos embriões perpassa entendimentos do presente, passado e também de futuros possíveis. Parte desses futuros são negociados a partir de uma disputa entre destinos "mais nobres": doação para adoção ou pesquisa. 


\section{Fertilização In Vitro e Embriões Extranumerários}

Quando retomamos a história da reprodução assistida (RA), ela quase sempre se inicia no nascimento do primeiro bebê de proveta no Reino Unido - Louise Brown, em 1978. Desse emblemático caso muito se beneficiou a reprodução assistida, já que esse foi o principal veículo de propagação da viabilidade dessas técnicas. Acrescentam-se aí as controvérsias que relatam a corrida para a consagração dos "pais" da FIV (fertilização in vitro) - os britânicos Edwards e Steptoe - e disputas acerca dos avanços e nascimento de outro bebê em 1978, dessa vez na Índia, com técnica desenvolvida por Subhas Mukerji - que enfrentou inúmeras imposições que impossibilitaram o reconhecimento de seus avanços e contribuições (BHARADWAJ, 2002). Retomamos a construção da narrativa de desenvolvimento dessas técnicas e controvérsias nelas muitas vezes invisibilizadas, pois acreditamos que essas políticas da ciência dizem muito sobre os modos de agenciamento e relações de poder em que estão envoltas as práticas da RA. Desse modo, atentamos que os múltiplos agenciamentos acerca do destino de embriões são disputas de poder, que envolvem aspectos técnicos, científicos, morais e governamentais.

Se a FIV foi uma técnica resultado de uma corrida tecnológica, para compreendermos o seu salto no desenvolvimento das tecnologias reprodutivas, é preciso situar a centralidade da estimulação ovariana e a passagem da manipulação do material genético de dentro para fora do corpo (STRATHERN, 1992). O desenvolvimento da embriologia e da estimulação faz parte de um longo processo de experimentação em mamíferos e sua transposição técnica para a reprodução humana (FRANKLIN, 2013). No entanto, foi a transição do local de tratamento e intervenção que permitiu que novas possibilidades e agentes fizessem parte dessa esfera da reprodução. Com a passagem para fora do corpo é possível que mulheres doem óvulos, como os homens doam esperma; é possível que mulheres gestem bebês para outrem; é possível analisar geneticamente os embriões produzidos e criopreservar os excedentes ${ }^{2}$. A possibilidade de doar óvulos e gestar para outrem criam na RA o que Cooper e Waldby (2014) chamam de "clinical

\footnotetext{
${ }^{2}$ Em outra ocasião desenvolvi as transformações dessa passagem de dentro para fora do corpo a partir da reflexão de Rose (2007) acerca da molecularização / molarização da ciência e sua interface com a saúde.
} 
labor". Trata-se do trabalho, em contexto clínico, de doadores de tecidos, como os gametas, que questiona as intersecções entre o desenvolvimento da ciência e direitos desses sujeitos numa "bioeconomia global".

\begin{abstract}
“A indústria farmacêutica demanda um número cada vez maior de indivíduos para testes a fim de alcançar os imperativos da inovação;o mercado da reprodução assistida continua a se expandir quando cada vez mais famílias buscam serviços de reprodução assistida de terceiros - vendedores de gametas e agenciadores de gestações substitutas; e os setores da produção de célulastronco buscam mais tecidos. A indústria das ciências da vida precisa de uma extensa e, ao mesmo tempo, pouco reconhecida força de trabalho, cujo serviço consiste na experiência visceral da experimentação de fármacos, transformações hormonais e procedimentos biomédicos mais ou menos invasivos, como ejaculação, retirada de tecidos e gestação. [...] Com a expansão das tecnologias de reprodução assistida, a venda de tecidos como óvulos e espermatozoides, ou serviços reprodutivos, como a gestação de substituição emergem em um florescente mercado de trabalho, que é altamente estratificado no que diz respeito à classe e raça. Nós nos referimos a essa forma de trabalho como trabalho clínico." (COOPER; WALDBY, 2014, p.7 tradução minha).
\end{abstract}

Trata-se de um processo de reconhecimento nas ciências sociais de que há múltiplos modos pelos quais processos biotécnicos centrados nas políticas da vida estão envolvidos em redes de transação comercial e de acumulação de capital. Nesse contexto, a produção de óvulos foi o aspecto da RA que mais se investiu de uma lógica "bioeconômica". Dito de outro modo, com o objetivo de maximizar a "eficiência" do tratamento, tornou-se necessário produzir mais embriões por ciclo. Para tanto, fez-se necessário produzir mais óvulos. É a estimulação ovariana que permite a maximização do capital biológico, pois, com a produção de mais óvulos, é possível produzir mais embriões e aumentar as chances de "sucesso" na transferência de embriões a cada ciclo. Nesse sentido, antes do embrião, a substância que está sendo produzida e almejada com maior capital ou "biovalor" são os óvulos.

Em meu campo de pesquisa ${ }^{3}$, realizado em um centro de reprodução

\footnotetext{
${ }^{3} \mathrm{O}$ trabalho de campo se desenvolveu de março a dezembro de 2014. Durante esse período tive acesso a relatórios e documentos de acompanhamento dos ciclos de reprodução assistida, bem como pude entrevistar formalmente alguns dos profissionais que atuam na clínica.
} 
assistida na cidade de Porto Alegre, pude dialogar com os profissionais envolvidos na utilização dessa técnica. Para o Dr. Alves ${ }^{4}$, diretor da clínica, os avanços tecnológicos que estão aplicados à estimulação ovariana, sobretudo no que diz respeito aos fármacos que são introduzidos para intensificar a produção de ovócitos, são seguros e precisos. Apesar dessa facilidade técnica, há uma fila para a obtenção de óvulos via doação. Trata-se da prática de doação compartilhada de óvulos (eggsharing), regulamentada pelo Conselho Federal de Medicina na Resolução 2.013/13. Nesse sentido, o Dr. Alves afirma que a estimulação ovariana não é o principal problema que encontram para produzir bons embriões ${ }^{5}$, e nem sempre a produção de um "bom número" de óvulos significa a produção de muitos embriões.

No entanto, existem contextos em que a produção de mais óvulos e embriões não é necessariamente bem-vinda ${ }^{6}$. Elisabeth Roberts (2007), antropóloga especialista em RA no Equador, México e EUA, mostra como no Equador a quantidade de óvulos produzida pode ser tencionada com questões éticas e financeiras. A pesquisa de Roberts mostra que duas regiões do Equador operam em diferentes lógicas no que diz respeito à produção de óvulos e, como consequência, de embriões. Em Quito, a autora observou uma forte hesitação quanto à possibilidade de congelar embriões, enquanto que em Guayaquil prevalece um entusiasmo diante dessa possibilidade técnica.

Entre seus interlocutores, a autora destacou aqueles que hesitavam em congelar embriões alegando impedimentos técnicos. Eles afirmavam que as perdas no processo de conservação e descongelamento desperdiçariam a vida dos embriões. Essa perspectiva compartilha a percepção de uma crueldade terapêutica já mencionada por outros autores e defendida por representantes da igreja católica, como exemplo (BHARADWAJ, 2012; ROBERTS, 2007). Já em Quito, seus interlocutores evitavam produzir embriões excedentes por um entendimento particular acerca do parentesco, questionando um possível descompasso quando um "membro" da família está congelado no tempo, fora de lugar. Para evitar o excesso de

\footnotetext{
${ }^{4}$ Todos os nomes utilizados aqui são pseudônimos.

5 Já discuti a importância do fator masculino para a produção de "bons embriões" em Allebrandt (2015 e 2017).

${ }^{6}$ Segundo Jasanoff (2005), a regulamentação alemã de proteção aos embriões proíbe embriões supranumerários. Na Noruega também existem preocupações com o congelamento prolongado de embriões - cujo limite permitido é de três anos (MELHUUS, 2005).
} 
embriões, as dosagens de medicamento para estimulação da ovulação eram cuidadosamente calculadas.

Roberts destaca ainda que, nesse mesmo contexto de pesquisa, entre os profissionais surgiu uma preocupação com a possibilidade de criopreservar embriões: o que fazer se a família "abandona" essa substância/pessoa/ parente nos tanques de nitrogênio das clínicas? Acrescenta-se aí que as clínicas de Quito e Guayaquil tinham programas de doação de embriões frescos para evitar o descarte. A dificuldade de aceitar a doação de embriões evocava relações de parentesco e partilha de substância que dificultavam a sua circulação. É interessante notar que um mesmo sentimento que torna o embrião conectado ao contexto de sua produção também é evocado para a recusa de sua criopreservação.

Contrariamente às preocupações encontradas por Roberts no Equador, no que diz respeito ao cuidado de não produzir embriões excedentes, a maioria dos centros de reprodução assistida com os quais tive contato na literatura e em minhas pesquisas no Brasil demonstram que a criopreservação é lugar-comum ${ }^{7}$ (CORRÊA, 2001; COSTA, 2001; TAMANINI, 2010; ALLEBRANDT; MACEDO, 2007; RAMÍREZ-GÁLVEZ, 2003; NASCIMENTO, 2009). Consequências dessa "acumulação" serão objeto de reflexão apenas décadas após o desenvolvimento da FIV e da possibilidade de criopreservação.

\section{Abundância de Embriões}

Nos EUA, um survey publicado em 2003 suscitou preocupações acerca do número de embriões congelados nas clínicas de RA (ROBERTS, 2007). Segundo esse survey, cerca de 400 mil embriões estariam congelados. Segundo Roberts, há razões para se acreditar que esse número é um tanto inflado: estimativas apontam que o Reino Unido tem 52 mil embriões congelados, enquanto que a Espanha contaria com 40 mil. No Brasil, reportagens veiculam a existência de 150 mil embriões congelados ${ }^{8}$.

\footnotetext{
${ }^{7}$ Nos meus diários de campo encontro apenas um relato em que um médico comentava as dificuldades de negociação do uso da RA com um cliente que era pastor de uma religião neopentecostal. Toda a discussão girou em torno do início da vida e do entendimento do que o embrião representava em sua forma celular.

8 Ver, por exemplo: http://g1.globo.com/jornal-nacional/noticia/2015/07/jn-mostradiscussao-delicada-sobre-destino-dos-embrioes-congelados.html .
} 
Por outro lado, o $9^{\circ}$ relatório anual do Sistema Nacional de Produção de Embriões (SisEmbrio) afirma que em 2015 foram congelados pouco mais de 67 mil embriões. Contabilizando os dados do SisEmbrio de 2012-2015, no Brasil há registro de mais de 185 mil embriões congelados 9 .

Gráfico 1 - Número de embriões congelados nos anos de 2012, 2013, 2014 e 2015 Número de Embriões congelados

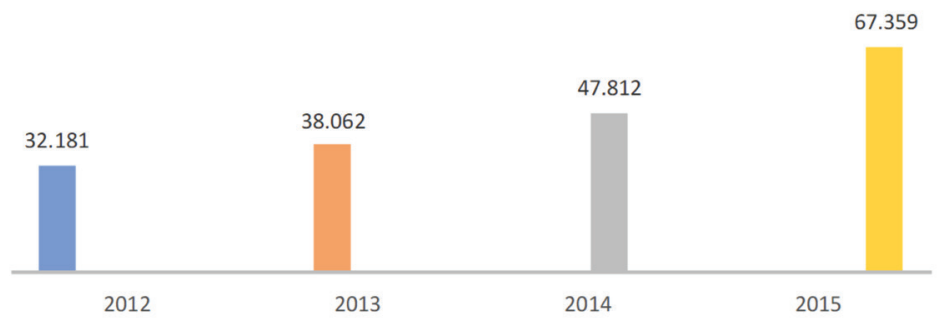

Fonte: SisEmbrio/Anvisa (2016). Dados obtidos em 18 de fevereiro de 2016.

A constatação da existência desse número considerável de embriões congelados no Brasil nos remete às orientações do CFM, que até a presente data, na ausência de uma legislação específica sobre o tema, é o único regulador das práticas de reprodução assistida. De 1990 até 2010, as orientações dessa resolução não previam o descarte de nenhum embrião. Na resolução de 2010 se fala no congelamento dos embriões viáveis, e somente em 2013 abre-se precedente para que embriões congelados há mais de cinco anos sejam descartados (conforme Quadro 1, que sistematiza as principais mudanças da regulamentação do CFM sobre esse assunto). Diante desse quadro de resoluções, o número de embriões congelados parece ser, ao mesmo tempo, produto desse impedimento no descarte e também resultado do aumento da utilização dessa técnica.

Desde 2013, quando há, na utilização das tecnologias de RA, a produção de embriões excedentes, os beneficiários dessas técnicas devem decidir qual destino desejam dar aos embriões congelados em caso de não pagamento da taxa anual e algumas situações previstas, como no exemplo seguinte,

\footnotetext{
${ }^{9}$ Diante da implementação do SisEmbrio, os primeiros relatórios apontavam a pouca adesão das clínicas de RA no envio de seus relatórios. Com base nesses dados, podemos compreender a dificuldade de aferir o número real de embriões congelados no Brasil.
} 
copiado do contrato de prestação de serviços da clínica onde realizei esta pesquisa.

“EM CASO DE NÃO PAGAMENTO DA TAXA DE MANUTENÇÃO ANUAL, DE DESISTÊNCIA, DE MORTE, SEPARAÇÃO OU INVALIDEZ DE QUALQUER UM DOS CÔNJUGES, O DESTINO DOS EMBRIÕES CONGELADOS SERÁ (escrever de próprio punho o destino dos embriões)".

(Retirado de diário de campo de 19 de maio de 2014, letras garrafais e pontuação conforme o contrato).

Segue esse parágrafo a escrita de próprio punho das pessoas que estão se submetendo aos tratamentos de RA. Ali redigem se desejam que os embriões sejam doados para outros casais ou para pesquisa, descartados ou ainda que nada seja feito com esse material.

Determinar o destino dos embriões não é um assunto que se toma em consideração apenas em contexto de abundância, como os dados parecem apontar ser o caso do Brasil. Decidir sobre seu destino é um tema que envolve concepções e éticas muito variadas e que fundamentaram a própria viabilidade da RA. O Reino Unido foi pioneiro nesses debates ${ }^{10}$.

Grande parte do debate britânico envolveu impasses acerca do entendimento de quando se dá o início da vida e se há no embrião um momento em que se possa limitar uma passagem entre conjunto de células e vida potencial (CESARINO, 2007; MULKAY, 1994). A decisão que compõe o texto legal foi da criação de uma outra categoria para esse conjunto de células - o "pré-embrião". No entendimento do parlamento, o pré-embrião é a categoria que permite a manipulação e experimentação desse conjunto de células até 14 dias após a fertilização. Segundo Cesarino, que comparou o caso britânico e brasileiro, o debate que ocorreu no Reino Unido se centrou em um ponto:

[...] a tensão central que envolve a definição de regras para o uso do embrião na pesquisa científica diz antes respeito a se (ou

10 É preciso notar que a utilização de embriões humanos em pesquisas teve um importante marco nos anos 1990, quando o Parlamento Britânico aprovou a regulamentação de procedimentos de RA e pesquisa embriológica através do Human Fertilisation and Embriology Act (HFEA). Esse relatório também ficou conhecido como Warnock Report, nome da filósofa Mary Warnock que presidiu os debates do comitê interdisciplinar que embasou os parâmetros dessa lei. 
quando) ele é sujeito humano ou não. Se ele resta no reino dos humanos plenos de direitos e dignidade ou se, ao contrário, é absolutamente objetificado, transferido para o reino da natureza não-humana. (CESARINO, 2007, p.348-349)

Inspirada pela discussão sobre o vínculo lançada por Latour (2004), a autora discute o estatuto do embrião a partir da sua capacidade de agenciar e vincular-se, alertando para a sua provisoriedade, a políticas da natureza e ontologias naturais. Outros autores têm preferido tratar essas tensões a partir do conceito de "coreografia ontológica" elaborado por Charis Thompson $(2005 ; 2014)$. Nesse sentido,

\begin{abstract}
“Limites na pesquisa com células-tronco são continuamente redesenhados. Esse processo envolve uma elaborada "coreografia ontológica" cercada de interfaces técnicas, biogenéticas e humanas com as "conexões ontológicas entre a tecnologia e o eu" tornando-as autoras de experiências e resultados [...]. Célulastronco, no entanto, estão implicadas no status ontológico de muito mais do que a forma embrionária[...]. O apagamento dos limites entre humano/animal e a criação de uma interseção interespécie estão entre os muitos desenvolvimentos científicos corolários da emergência das células-tronco. Isso é especialmente verdade pelo fato de os avanços na pesquisa com células-tronco serem desafiadores e redesenharem os limites entre noções culturais do natural e artificial, vida e morte, materialidade e potencialidade senciente, ética e imoralidade, sagrado e profano, limpo e sujo". (BHARADWAJ, 2012, p.306 tradução minha)
\end{abstract}

Em Portugal, uma legislação publicada em 2006 regulamenta a RA (Lei 32/2006) e prevê dois destinos para os embriões baseados na sua classificação de viabilidade - aqueles embriões que estão envolvidos num projeto parental e devem ser transferidos ou doados para outro casal e aqueles sem possibilidade de envolvimento em um projeto parental, cujo destino pode ser a investigação científica. Para essa última possibilidade é preciso que a pessoa/casal dê seu consentimento. Silva et al. (2016) problematizam o lugar do consentimento informado para a doação de embriões para fins científicos. Segundo os autores, o consentimento emerge como um símbolo da escolha e na negociação do destino dos embriões; essa escolha revela a não rigidez dos parâmetros e conceitos que envolvem o embrião. Os autores nos lembram também que diferentemente das práticas que encontraram em suas pesquisas, na legislação portuguesa está previsto 
que se crie um sistema para doação de embriões que funcionaria como o sistema de doadores de órgãos biológicos. Nesse caso, aqueles que não desejassem doar seus embriões para a investigação científica deveriam declarar sua posição.

No Brasil, a ausência de um debate público sobre os limites e políticas da RA e do uso de embriões para pesquisa intrigou vários pesquisadores (ALLEBRANDT, 2009; ALLEBRANDT; MACEDO 2007; CESARINO, 2007; LUNA, 2012; ROCHA, 2015). Cesarino (2007) relata com precisão como a pesquisa com células-tronco entrou no debate do Projeto de Lei da Biossegurança. A necessidade de se legislar acerca dos embriões foi embalada com estimativas da existência de 20 a 30 mil embriões congelados e o lobby pró-pesquisa contou com uma audiência pública em 2004.

Segundo o estudo realizado por Diniz e Alvelino (2009) comparando 25 países diante da pesquisa com embriões, a legislação brasileira tem particularidades e semelhanças com a legislação portuguesa que exploramos.

“Uma particularidade da Lei brasileira n. ${ }^{\circ}$ 11.105/2005 foi determinar que a pesquisa deve ser preferencialmente conduzida com embriões inviáveis. Nenhum dos 25 países analisados estabelece a diferenciação legal entre embriões congelados viáveis e inviáveis para a pesquisa científica, exceto, com outros termos, o art. $9^{\circ}$ da Lei 32/2006 de Portugal. A tendência internacional é demarcar a distinção entre embriões congelados remanescentes de projetos reprodutivos e embriões produzidos para fins exclusivos de pesquisa científica, havendo uma maior harmonia em reconhecer como legítima a investigação com embriões congelados, não autorizando sua produção exclusivamente para pesquisa". (DINIZ; AVELINO 2009, p.545)

Ambas regulamentações preveem a doação de embriões viáveis para pesquisa quando eles estiverem congelados há mais de três ou cinco anos, respectivamente. O controle e gestão dessas prerrogativas passa no quadro legislativo brasileiro junto da Lei de Biossegurança (Lei $\left.n^{0} 11.105 / 2005\right)$, pela criação do SisEmbrio.

A criação desse sistema faz parte do esforço estatal em implementar um controle dos embriões que foram produzidos no país. Tal sistema entrou em vigor através da Resolução da Diretoria Colegiada (RDC) número 29, parte da Agência Nacional de Vigilância Sanitária (ANVISA).

Em 2008, esse sistema realizou a publicação de seu primeiro relatório 
anual contabilizando os embriões produzidos e congelados no Brasil. Pensado como um banco de dados acerca da manipulação dos tecidos germinativos em todo o Brasil, o SisEmbrio depende dos dados que as clínicas e centros de reprodução assistida deverão fornecer anualmente. Trata-se de número de óvulos que foram produzidos, fecundados, transferidos, criopreservados, descartados e doados para a pesquisa. Segundo o primeiro relatório do SisEmbrio, até 28 de março de 2005 - data da promulgação da Lei de Biossegurança (Lei no 11.105/2005) -, existiam no Brasil 25.120 embriões disponíveis para a pesquisa. Além disso, o relatório contabiliza outros 20.062 embriões não disponíveis para pesquisa. É importante notar que apenas 50 dos estimados 120 Bancos de Gametas e Tecidos Germinativos (BCTG) enviaram seus dados para compor o relatório. O relatório seguinte contou com os mesmos entraves, apesar do alerta de que o não fornecer tais dados incorre uma infração sanitária que possibilita penalidades e até mesmo o fechamento de tais centros.

"Segundo informações cedidas pela Sociedade Brasileira de Reprodução Assistida (SBRA) existem cerca de 120 BCTG no Brasil. Cabe enfatizar que este ano os BCTG que não informaram no SisEmbrio os dados de produção requeridos pela RDC n. ${ }^{\circ 29 / 08}$ serão notificados pela Gerência de Tecidos, Células e Órgãos - GETOR/ANVISA e incorrerão em infração sanitária, sujeitos a penalidades previstas na Lei $\mathrm{n}^{\circ} 6.437$, de 20 de agosto de 1977. (4º Relatório Sis Embrio).

Considerando que o universo estimado para os Bancos de Células e Tecidos Germinativos no Brasil é de 120 serviços, o percentual de adesão dos mesmos ao SisEmbrio (77-65\%) ainda é baixo. (5 Relatório SisEmbrio)."

Notamos que apenas no $8^{\circ}$ e $9^{\circ}$ Relatórios o SisEmbrio parece conseguir obter as informações necessárias ao seu funcionamento. Tais entraves são bastante emblemáticos da dificuldade do estado em estabelecer qualquer prática de governança, política de controle e acompanhamento com relação às clínicas de RA e seus procedimentos ${ }^{11}$ (ACERO, 2011; JASANOFF, 2005).

\footnotetext{
${ }^{11}$ É importante lembrar que até 2005 não havia nenhuma legislação nacional que interferisse nas práticas de RA para além das resoluções do CFM. Pode-se dizer, portanto, que o controle de tecidos e células germinativas é a primeira investida do estado para esse fim.
} 
Apesar dessa inércia em fornecer dados, o CFM parece aguardar uma legislação a respeito da RA e demonstra-se ansioso nessa espera em um anexo da reformulação de sua resolução sobre o tema em 2013. Cabe notar que a primeira resolução acompanhou movimentos reguladores em todo o mundo no início da década de 90. Tal resolução veio a ser reescrita apenas em 2010, seguida por modificações em 2013 e 2015 (conforme Quadro 1).

Entre as principais mudanças, vemos que, na resolução do CFM de 2010 (CFM 1.957 / 2010), entra em vigor um novo entendimento de quais embriões devem ser congelados. Segundo essa resolução, somente embriões viáveis devem ser congelados. Essa orientação inviabilizaria grande parte das pesquisas desenvolvidas com embriões, já que elas teriam sua base em embriões inviáveis.

Quadro 1 - Resoluções do CFM e sua deliberação quanto ao descarte e doação de embriões

\begin{tabular}{|c|c|c|}
\hline & Descarte de Embriões & Doação de Embriões \\
\hline $\begin{array}{l}\text { Resolução } \\
\text { CFM } \\
1.3581992\end{array}$ & $\begin{array}{l}\text { Art. V } 2 \text { - O número total de } \\
\text { pré-embriões produzidos em } \\
\text { laboratório será comunicado aos } \\
\text { pacientes, para que se decida } \\
\text { quantos pré-embriões serão } \\
\text { transferidos a fresco, devendo } \\
\text { o excedente ser criopreservado, } \\
\text { não podendo ser descartado ou } \\
\text { destruído. }\end{array}$ & $\begin{array}{l}3 \text { - No momento da } \\
\text { criopreservação, os cônjuges ou } \\
\text { companheiros devem expressar } \\
\text { sua vontade, por escrito, quanto } \\
\text { ao destino que será dado aos } \\
\text { pré-embriões criopreservados, } \\
\text { em caso de divórcio, doenças } \\
\text { graves ou de falecimento de um } \\
\text { deles ou de ambos, e quando } \\
\text { desejam doá-los. }\end{array}$ \\
\hline $\begin{array}{l}\text { Resolução } \\
\text { CFM } \\
1.9572010\end{array}$ & $\begin{array}{l}\text { Art. V - } 2 \text { - Do número total } \\
\text { de embriões produzidos em } \\
\text { laboratório, os excedentes, } \\
\text { viáveis, serão criopreservados. }\end{array}$ & Mantém a escrita do Art V - 3 \\
\hline
\end{tabular}




\begin{tabular}{|c|c|c|}
\hline & Descarte de Embriões & Doação de Embriões \\
\hline $\begin{array}{l}\text { Resolução } \\
\text { CFM } \\
2.0132013\end{array}$ & $\begin{array}{l}\text { O número total de embriões } \\
\text { gerados em laboratório será } \\
\text { comunicado aos pacientes para } \\
\text { que decidam quantos embriões } \\
\text { serão transferidos a fresco. Os } \\
\text { excedentes, viáveis, devem ser } \\
\text { criopreservados. } \\
4 \text { - Os embriões criopreservados } \\
\text { com mais de } 5 \text { (cinco) anos } \\
\text { poderão ser descartados } \\
\text { se esta for a vontade dos } \\
\text { pacientes, e não apenas para } \\
\text { pesquisas de células-tronco, } \\
\text { conforme previsto na Lei de } \\
\text { Biossegurança. }\end{array}$ & $\begin{array}{l}\text { Mantém a escrita do Art V - } 3 \\
\text { Acrescenta: Art. IV } \\
\text { [...] } \\
\text { 4- Será mantido, } \\
\text { obrigatoriamente, o sigilo sobre } \\
\text { a identidade dos doadores de } \\
\text { gametas e embriões, bem como } \\
\text { dos receptores. Em situações } \\
\text { especiais, informações sobre } \\
\text { os doadores, por motivação } \\
\text { médica, podem ser fornecidas } \\
\text { exclusivamente para médicos, } \\
\text { resguardando-se a identidade } \\
\text { civil do(a) doador(a).[...] }\end{array}$ \\
\hline $\begin{array}{l}\text { Resolução } \\
\text { CFM } \\
2.1212015\end{array}$ & $\begin{array}{l}4 \text { - Os embriões criopreservados } \\
\text { com mais de cinco anos poderão } \\
\text { ser descartados se esta for } \\
\text { a vontade dos pacientes. A } \\
\text { utilização dos embriões em } \\
\text { pesquisas de células-tronco não } \\
\text { é obrigatória, conforme previsto } \\
\text { na Lei de Biossegurança. }\end{array}$ & $\begin{array}{l}\text { Mantém a escrita dos Art. IV } \\
\text { e V }\end{array}$ \\
\hline
\end{tabular}

Fonte: Conselho Federal de Medicina - grifos da autora.

Na resolução de 2013 (CFM 2.013 2013) há um anexo à nova redação: “EXPOSIÇÃO DE MOTIVOS DA RESOLUÇÃO CFM n ${ }^{\circ}$ 2.013/13”. Nesse documento, José Hiran da Silva Gallo, Coordenador da Comissão de Revisão da Resolução CFM n ${ }^{0} 1.358 / 92$ afirma:

“A Resolução CFM no 1.957/10 mostrou-se satisfatória e eficaz, balizando o controle dos processos de fertilização assistida. No entanto, as mudanças sociais e a constante e rápida evolução científica nessa área tornaram necessária a sua revisão. Uma insistente e reiterada solicitação das clínicas de fertilidade de todo o país foi a abordagem sobre o descarte de embriões congelados, alguns até com mais de 20 (vinte) anos, em abandono e entulhando os serviços. A comissão revisora observou que a Lei de Biossegurança (Lei no 11.105/05), em seu artigo 5º inciso II, já autorizava o descarte de embriões congelados há 3 (três) anos, contados a 
partir da data do congelamento, para uso em pesquisas sobre células-tronco. A proposta é ampliar o prazo para 5 (cinco) anos, e nãa só para pesquisas sobre células-tronco" ". (grifo meu).

Segundo essa carta, os embriões congelados nas clínicas se encontram entre abandono e entulho. $\mathrm{O}$ medo do abandono foi um dos argumentos encontrados por Roberts para evitar o congelamento de embriões (ROBERTS, 2007; ROBERTS, 2011). Falar em abandono de embriões remete a um discurso muito evocado nas relações familiares e práticas de adoção (FONSECA, 2012; FONSECA, 2009). Fonseca (2012) nos chama atenção para os múltiplos significados do termo abandono e como há nele polarizações que extremam a uma indiscriminada criminalização de mães que dão seus filhos em adoção. Fonseca (2009) afirma que está implícito na palavra abandono uma rejeição emocional, que não corresponde às práticas de adoção, sobretudo quando explora o contexto em que estão implicadas a maioria das mães que abriram mão de seu poder familiar. Na nota do CFM, o abandono também aponta para uma rejeição emocional, já que esses embriões esquecidos há 20 anos, provavelmente, não fazem mais parte de um projeto familiar.

A segunda relação evocada para o entendimento dos embriões é que eles seriam entulho. Trata-se de uma imagem dificilmente associada aos assépticos tanques de nitrogênio das clínicas de RA. No entanto, os embriões representam um acúmulo indesejável. Eles são lixo. Mas como não são produto de apenas uma categoria, descartá-los implica a necessidade de autorização por parte dos "genitores"(LUNA, 2007).

Durante minha pesquisa de campo, o que fazer com os embriões congelados que se acumulavam nos tanques de nitrogênio da clínica que comemorava 10 anos de existência foi apresentado como um problema cotidiano. Vamos examinar mais de perto os usos e a flexibilidade com que são tratados os embriões nesse cotidiano. 
Procedimento: ICSI - Sêmen fresco. Bordas e cabeçalho da imagem foram retirados para não identificação da clínica.

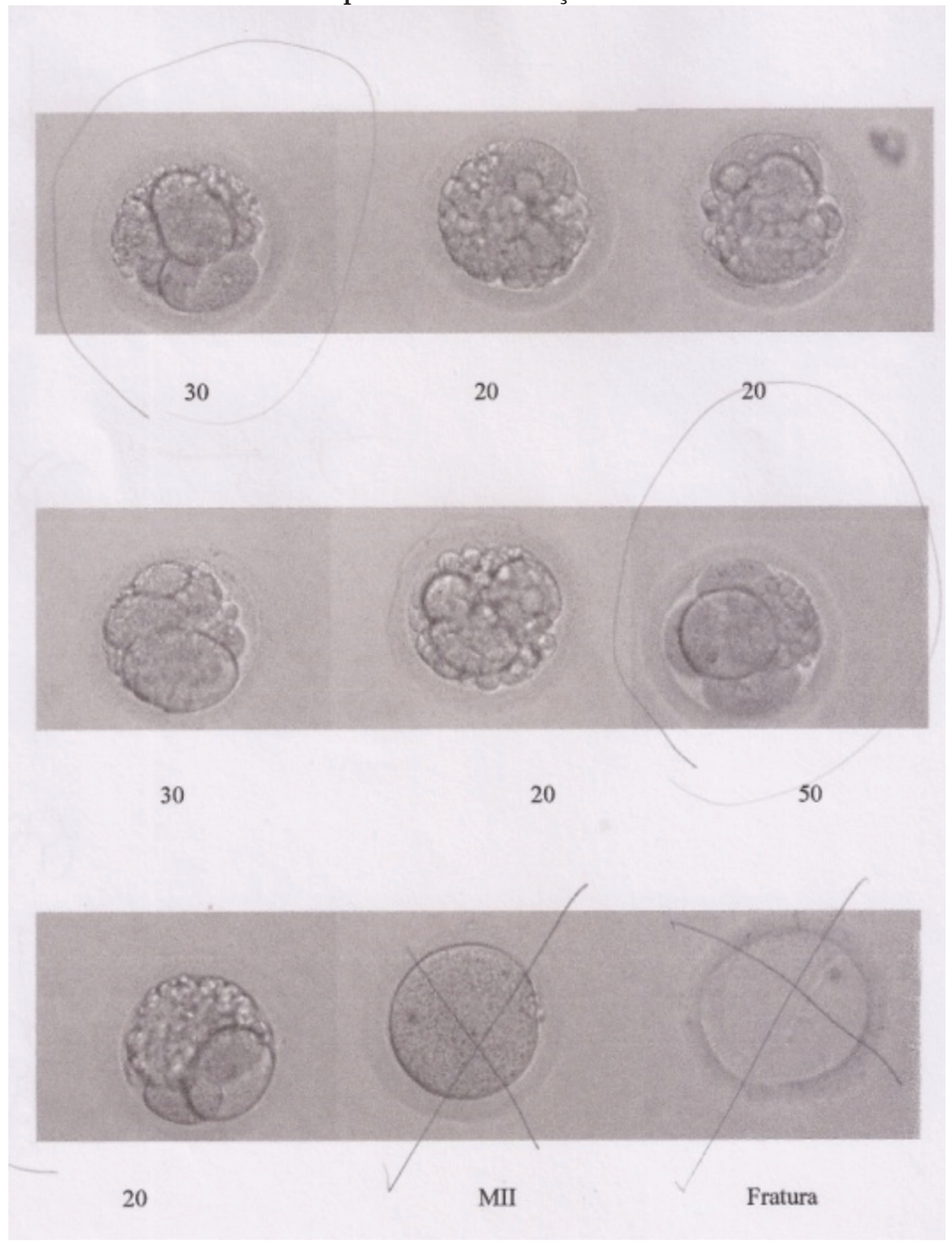

Fonte: Material digitalizado pela autora com autorização da clínica. 


\section{Passado e Presente de Embriões: Tempo, Memória e Imagens de Viabilidade}

Na fala do Coordenador da Comissão de Revisão da Resolução CFM n ${ }^{0}$ 1.358/92, o tempo é um fator importante para a negociação do destino dos embriões. "Alguns até com mais de 20 (vinte) anos" é frase que nos ajuda a situar os modos de tratamento "abandono" e "entulho", que fundamentarão a possibilidade de descarte desses embriões. Nesta seção, quero explorar dois aspectos que considero importantes para negociar o significado e destino dos embriões: o passado e o presente.

Durante minha pesquisa de campo, despertou meu interesse uma nova prática que passou a fazer parte da rotina da clínica. Enquanto me familiarizava com os prontuários, via com frequência a presença de imagens de embriões, relatando a data da transferência, a técnica utilizada e um número abaixo dessas imagens. Quando perguntei ao Dr. Alves o que eram aqueles números, ele me explicou que era uma técnica, o Graduate Embryo Score ${ }^{12}$, que havia sido implementada pela embriologista da clínica, me recomendando que, se eu tivesse interesse em saber mais, que a procurasse. Entusiasta das novas tecnologias, Dr. Alves afirmou que essa técnica estava surtindo bons efeitos, de modo que ele não deixava mais as pacientes entrarem na sala de transferência sem ter visto os embriões.

\footnotetext{
“Eu não deixo mais que uma paciente faça a transferência sem ver os embriões. [....] Eu uso essa folhinha [pega uma pilha de folhas com imagens de embriões, nome das pacientes, data e o tipo de procedimento no armário atrás de sua mesa], porque você sabe, é um tratamento caro e você não vê sempre o resultado... isso ajuda também a explicar por que não está dando certo. Olha esse aqui por exemplo [mostra a imagem acima]... ela, com ela está tudo certo. A estimulação foi um sucesso. Mas o esperma, ele, ele é o problema. Aí você tem aquele monte de óvulos que viram esses embriões aqui... tudo ruim...".

(Fala do Dr. Alves em diário de campo).
}

12 Já discuti essa questão durante a XI Reunião de Antropologia do Mercosul. Agradeço a Fabíola Rohden e Alejandra Roca, coordenadoras do instigante grupo de trabalho no qual pude apresentar uma primeira versão desse artigo, pelos seus preciosos comentários e sugestões. 
Esse tipo de visualização do tratamento ajuda a mostrar o que é feito no laboratório e explicar, em parte, que o grande investimento realizado não foi somente para a injeção de um "líquido transparente" (GRUDZINSKI, 2009). Ver os embriões pode ajudar a produzir um bom resultado no tratamento, deixando os clientes mais otimistas em relação a bons resultados, além, é claro, de mediar a escolha de quais embriões transferir e se é interessante criopreservar ou doar para a pesquisa os embriões supranumerários. Nesse sentido, a imagem dos embriões ajuda a fundamentar a viabilidade dos embriões. Por outro lado, ver os embriões e receber explicações que atestam sua "qualidade ruim" é uma ferramenta que os profissionais tentam utilizar para o esclarecimento dos casais para a necessidade de utilização de técnicas complementares.

Como já afirmei em trabalhos anteriores (ALLEBRANDT, 2015; 2017), as dinâmicas que envolvem o uso da Graduate Embryo Score são muitas e envolvem diversas camadas de complexas relações e conexões. Tomo neste artigo o GES como uma ferramenta que permite o agenciamento no presente daqueles que fazem uso das tecnologias de reprodução assistida.

No início desta pesquisa, realizei um longo trabalho de levantamento de dados em prontuários clínicos e documentos de registro da clínica. Ficou reservado pelo Dr. Alves o meu acesso à clínica nas segundas-feiras à tarde, quando ele se encontrava em seu outro local de prática médica. Habitualmente, segunda-feira era um dia muito tranquilo na clínica. Apenas um dos médicos costumava atender suas clientes, e no turno da tarde não aconteciam procedimentos de RA, que estavam concentrados nas manhãs.

Numa dessas segundas-feiras, enquanto lia os prontuários, começo a ouvir diálogos repetitivos que me distraem da leitura dos prontuários. Reproduzo uma das interações que registrei no meu diário de campo.

Boa tarde, eu poderia falar com Joana? [pausa]

Oi Joana, aqui é a Roberta da clínica "Fertilizar", tudo bem?[pausa] Então, Joana. Eu estou te ligando pra falar sobre os embriões que você tem congelados aqui na clínica. [longa pausa].

Sei. Sei [longa pausa].

A taxa custa hoje $\mathrm{R} \$ 500,00$. [pausa]

o.k., certo. [pausa curta]

Você quer descartar? [pausa curta] Certo.

Então fazemos assim: eu preciso que você assine um formulário. Você quer passar aqui na clínica? [pausa]

Então eu te envio o formulário por e-mail e você me entrega ele assinado, pode ser? [pausa curta] 
Ótimo. Então, confirmando o teu e-mail é joana@gmail.com. [pausa]

Ótimo. Eu te envio o formulário agora. Muito obrigada! Tchau.

Logo em seguida ouço o mesmo tom cordial e alegre refazendo a ligação para outra cliente. $\mathrm{O}$ mesmo roteiro se repetia. Fiquei curiosa, e com a desculpa de buscar um copo com água, fui ver quem estava fazendo essas ligações. Pergunto para a simpática secretária - que mesmo depois de meses de pesquisa de campo ainda acredita que sou representante de um laboratório -, quem é a moça que está ligando e ela me responde que é a Júlia, nova na clínica.

Júlia está confortavelmente sentada em um divã, com as pernas casualmente cruzadas. Ela tem um computador portátil em seu colo, no qual faz anotações sobre as ligações que acaba de fazer. As cortinas da sala estão abertas, e ela aproveita o sol depois de dias de muito frio do inverno gaúcho na bela sala que acolhe as pacientes da clínica que irão transferir embriões ou extrair óvulos. Ela está usando um jaleco branco e sobre o seu sapato pantufas protetoras, já que está em uma sala limpa ${ }^{13}$. Entre uma ligação e outra, vou até a porta e me apresento. Explico o que estou fazendo ali e digo que me interessei pelas suas ligações. Ela, por outro lado, parece entediada, exatamente o contrário do que me dava impressão ao ouvi-la falando alegremente ao telefone com os clientes.

Ela me diz que esse é um trabalho enfadonho. Comenta que nesse dia teve sorte. Muitas vezes as pessoas não querem falar sobre o assunto e desligam na sua cara. Mas pondera dizendo que faz parte do trabalho. Volto para meus prontuários lentamente enquanto ouço Júlia resolver em minutos o destino de outros embriões. Depois de tanto estudar a ausência involuntária de filhos, essa foi a primeira vez que ouvi embriões serem tratados de uma maneira tão pragmática, quase como substâncias livres de conexão e passíveis de descarte/doação.

Em outro momento, comento com Dr. Alves que conheci Júlia e a ouvi fazendo essas ligações. Dr. Alves é enfático na sua avaliação desse ritual anual de acompanhamento dos embriões congelados:

\footnotetext{
${ }^{13}$ A limpeza do ar do laboratório e sala de transferência é um ponto central no funcionamento das clínicas de RA. A sala aonde está o divã é uma sala de espera, considerada limpa, nela só se pode entrar usando as vestes e sapatos laboratoriais. Na sala de transferência e no pequeno laboratório não há circulação de pessoas.
} 


\begin{abstract}
“Isso é infernal, mas temos que fazer! É um horror! Veja só, muitas das nossas pacientes se desiludem com a RA. A gente não promete o que não pode cumprir, todos sabem das taxas de sucesso, mas há aqueles que ficam amargurados... não querem mais falar disso, têm raiva da clínica... Outros já tiveram seus filhos e esqueceram dos embriões... ou não conseguem decidir se vão utilizar ou não. Enquanto isso nossos tanques [de nitrogênio] estão cheios [de embriões]. O que você tem que ver é que a gente não pode fazer nada sem o consentimento por escrito. Precisamos disso pra fazer qualquer coisa." [Fala do Dr. Alves, registrada em diário de campo].
\end{abstract}

Nesses procedimentos anuais, que me chocaram inicialmente por seu pragmatismo, existem conflitos e expectativas que, apreendemos na fala de Dr. Alves, são resultado de uma história com a RA ${ }^{14}$. A possível ineficiência das técnicas pesa em muitas das ligações, e as exigências formais de controle fazem com que muitas vezes a clínica se veja amarrada com um material indesejável. Tomo o ritual de negociação das taxas de manutenção dos embriões como um modo de aferir o passado e lidar com a memória do uso da RA. É nesse deslocamento temporal que os embriões podem ser tratados como "descartáveis", já que estão associados a "sonhos do passado" e não a um projeto presente (COSTA, 2002). Cabe então perguntarmos: quais são os futuros possíveis para os embriões produzidos na RA?

\title{
Futuros Possiveis? Qual é o Destino dos Embriões Doados para Pesquisa e para Doação?
}

Diante dos dados que quantificam a vida em potencial refrigerada em tanques de nitrogênio, emergem debates de grande efervescência que

\footnotetext{
${ }^{14}$ Dedico-me ao estudo da RA e de dinâmicas familiares há mais de uma década. Meu estranhamento durante esse período de tempo constituiu-se em muitas frentes. Construí com empatia pelo sofrimento que a ausência involuntária de filhos pode causar, a compreensão e o respeito das escolhas daqueles que utilizam a grandes custos e empenho emocional e financeiro as técnicas de RA. Foi justamente a compreensão desse grande esforço que produziu um novo estranhamento. Quando ouvi as narrativas de "desapego" diante dos embriões tão arduamente produzidos, fiquei chocada, pois não conseguia encaixar na narrativa de importância e essencialidade dos embriões um lugar tão pragmático para seu descarte. No entanto, a retomada da história de cada pessoa que fez uso desses procedimentos, suas tentativas, frustrações e pesares ajuda a colocar uma nova luz diante desse pragmatismo que pode estar associado não somente ao custo financeiro da manutenção desses materiais, mas também a mudanças nos projetos individuais e familiares.
} 
fundamentam posicionamentos pró-vida e pró-pesquisa ${ }^{15}$. Nas iniciativas pró-vida, programas de "adoção de embriões", na maioria deles encampados por organizações religiosas, sobretudo nos EUA, buscam oferecer um "destino melhor" aos embriões (COLLARD; KASHMERI, 2011; ROBERTS, 2011).

No Brasil, a adoção de embriões éincipiente e parte de iniciativas pontuais de clínicas de RA. Algumas pesquisas têm comparado adoção e reprodução assistida, apontam um conservadorismo com relação a práticas de adoção e pode dar pistas da dificuldade de adesão à adoção de embriões (FONSECA, 1995; RAMÍREZ-GÁLVEZ, 2011; ALLEBRANDT, 2007; ALLEBRANDT, 2013; ABREU, 2002). Além disso, questões relativas à circulação do material genético daqueles que têm seus embriões congelados e os modos como a genética tem se tornado um fator importante para a identidade também devem ser considerados (LUNA, 2005; GIBBON, NOVAS 2008; KLOTZ, 2015; BESTARD, 2012).

Do outro lado do debate, estão aqueles que defendem que a pesquisa com células-tronco embrionárias garante um "destino nobre" a essas células. Esse uso garantiria o "futuro" de todos, no sentido em que, utilizando esse material para pesquisa, estaríamos avançando rumo ao bem comum. A doação de embriões e toda a retórica de um "destino nobre" parece interessar grande parte dos clientes da clínica em que realizei meu campo. Nos documentos e contratos com os quais tive contato durante a pesquisa de campo, o descarte e a doação para pesquisa eram os destinos mais comuns redigidos nos campos apropriados.

Roberts (2007) mostra através da comparação das preocupações com o uso e destino de embriões no Equador e EUA o quanto existe um debate sobre éticas (do parentesco e da vida) que visam problematizar o futuro. Em 2005, nos EUA, o governo Bush fez um pronunciamento aliando-se aos lobbies pró-vida para barrar o financiamento de pesquisas com célulastronco com uma campanha para que os embriões disponíveis tivessem um destino "mais nobre": o da adoção. Com tal apelo associado ao vasto número de embriões supostamente disponíveis para tal fim, parece contraditório quando Roberts se confronta com outros contextos que mostram que "não é

\footnotetext{
${ }^{15}$ Existe ainda uma possibilidade que está para além dos lobbies pró-pesquisa e pró-vida que aparece no trabalho de campo de Roberts (2007), que é a ideia de "boa morte" - que significa retirar os embriões do processo de criopreservação e deixá-los perecer naturalmente.
} 
tão fácil quanto parece adotar um embrião". Isso se deve, sobretudo, ao fato que muitos casais não conseguem desconectar os embriões da substância marcadora de transmissão, que são os genes.

Diante de tal dificuldade, devemos observar que, desde a resolução de 1992 do CFM, há espaço para a doação de embriões no Brasil. No entanto, são raras as ocasiões em que essa possibilidade é considerada. No entanto, o marco da eventualidade de doação de embriões para a pesquisa data por volta 2005, com os debates e aprovação da Lei de Biossegurança.

Quadro 2 - Total de embriões doados para pesquisa 2007-2013

\begin{tabular}{|c|c|}
\hline Ano & Número de embriões doados \\
\hline 2007 & 643 \\
\hline 2008 & 382 \\
\hline 2009 & 490 \\
\hline 2010 & 748 \\
\hline 2011 & 1322 \\
\hline 2012 & 315 \\
\hline 2013 & 1231 \\
\hline Total & 5131 \\
\hline
\end{tabular}

Fonte: SisEmbrio/Anvisa (2014). Dados obtidos em 27 de março de 2014.

Quadro 3 - Total de embriões doados para pesquisa 2007-2014

\begin{tabular}{|c|c|}
\hline Ano & Número de embriões doados \\
\hline 2007 & - \\
\hline 2008 & 220 \\
\hline 2009 & 74 \\
\hline 2010 & 194 \\
\hline 2011 & 29 \\
\hline 2012 & - \\
\hline 2013 & 366 \\
\hline 2014 & 227 \\
\hline Total & 1110 \\
\hline
\end{tabular}

Fonte: SisEmbrio/Anvisa (2015). Dados obtidos em 20 de fevereiro de 2015.

O SisEmbrio revelou um importante erro no entendimento do que é doar embriões para pesquisa. Até o $7^{\circ}$ Relatório do SisEmbrio eram 
contabilizados todos os embriões com intenção de serem doados como se eles efetivamente tivessem sido doados para a pesquisa. Desse modo, ao invés dos 5.131 embriões doados para pesquisa, a contabilidade das doações é completamente diferente. Trata-se de 1.110 embriões efetivamente doados para pesquisa.

Tal constatação é reforçada por uma conversa que tive com o Dr. Alves, quando comentei estar impressionada com o número de pacientes que havia declarado desejar doar os embriões para pesquisa. Rindo de minha ingenuidade, Dr. Alves me dizia que isso não queria dizer nada. "Aqui[no Brasil] ninguém tem coragem de mexer com isso [embriões humanos]. Todos esses que tu viu aí [apontando para os prontuários] continuam aqui! Nenhum deles saiu daqui da clínica!"

Os diversos agenciamentos dos embriões nos assinalam que há uma transformação e flexibilidade dos significados e entendimentos do que é o embrião. Ele aparece como a prova da eficiência da técnica; sua imagem é utilizada para fundamentar a escolha dos tratamentos; sua imagem é utilizada para discutir chances de nidação e escolha de quais embriões devem ser implantados e/ou congelados; uma regulamentação datada faz com que todos embriões sejam congelados, posteriormente permite seu descarte/doação; lobbies pró-vida procuram ganhá-los para adoção, lobbies pró-pesquisa procuram engajá-los na descoberta de um futuro melhor. Ora família, linhagem; ora entulho; ora matéria-prima para o futuro. Apesar disso, parece que a sua circulação permanece hipotética.

Podemos entender embriões e células-tronco como entidades que são conceituadas na interseção da biologia, ontologia e epistemologia (BHARADWAJ, 2012). Embriões são parte do idioma da família. Evocam parentesco de modo tão direto que podemos pensar em seu abandono e posterior adoção. Quando suas fotografias são ritualmente apresentadas antes dos procedimentos de RA, eles representam o futuro, a esperança. Duas semanas depois, podem estar esquecidos em meio ao luto de uma perda e misturados no sangue que pode ser significado como menstrual (MANICA, 2016; MANICA, 2011; CARSTEN, 2013).

Embriões também são entulho, muitas vezes são tomados como "feios" (ROCA, 2004), estão estragados, são descartados independentemente da lei/regulamentação. Mas eles também são vistos como o futuro da ciência, portas para um mundo melhor, e nesse processo em que são super-heróis (SILVA et al., 2016), serão transformados e/ou descartados. 


\section{Considerações Finais}

Busquei neste artigo percorrer alguns dos caminhos que circundam a discussão acerca do destino de embriões no campo da RA, abordando, especialmente, a criopreservação, o descarte e a doação. Tratei a construção da criopreservação como uma ferramenta técnica que, aliada aos avanços da estimulação ovariana, produziu valores negociados em uma bioeconomia que reflete o desejo de filhos. A partir da difusão de ideias de abundância, foram capitalizadas noções de desperdício. Ela serviu tanto para enfatizar os embriões congelados que "entulham" tanques de nitrogênio e foram "abandonados" por aqueles que os construíram como projeto parental, quanto para lembrar que esses embriões podem ter um destino nobre e ser a chave de um futuro melhor, através de inéditas terapias com célulastronco.

Nota-se aqui um movimento que transforma os agenciamentos éticos em relação aos entendimentos do que são embriões. Na emergência da RA, o debate britânico deu o tom do cuidado para com o uso de embriões criando uma categoria anterior - o pré-embrião. Essa categoria, que serviu para acalmar os ânimos do acalorado debate britânico, foi tacitamente transportada para a Resolução 1.358 de 1992, que delimitou os limites éticos da RA e permaneceu como única referência até 2005, quando vêm à tona os debates da Lei de Biossegurança. É justamente em 2005, no contexto narrado como de abundância de embriões disponíveis para pesquisa e diante do grande desperdício que se aliava a seu potencial congelado, que os embriões passam a ser potencialmente utilizados em pesquisa.

Desse grande interesse em doação para pesquisa, o futuro dos embriões parece estar traçado por deslocamentos de fins e meios. No entanto, dados do SisEmbrio demonstram que no próprio entendimento da doação havia um dissenso. Ora, doar embriões para pesquisa aparece nos relatórios até 2013 como "intenção" de doar. Somente em 2014 que a contabilização passou a somar embriões efetivamente doados para pesquisa. De todo modo, o número inflado das pretendidas doações e das doações concretizadas está muito distante do número de embriões tomados como abandonados, desperdiçados e entulhando os centros de RA - aqueles que motivaram a inclusão na lei de biossegurança dos termos para pesquisa com embriões e informam também a nova escrita da Resolução do CFM. A suposta abundância de embriões em tanques de nitrogênio não é equacionada automaticamente como embriões para pesquisa. Éticas distintas e maleáveis 
agenciam tanto o entendimento de quantos embriões se deve produzir por ciclo como qual é o máximo de embriões que pode armazenar um dado país.

Em ambos os contextos o tempo figura como um elemento-chave. É com o tempo que alguns projetos parentais deixam de ter sentido quando os embriões foram congelados. Nessa lógica, um embrião criopreservado por 20 anos foi abandonado ou é um entulho? A resposta a essa pergunta depende de muitas éticas. O pragmatismo científico pode afirmar que a resposta está na viabilidade desse material. Hoje sua viabilidade é disputada entre possibilidades de seu uso para adoção e para pesquisa. O descarte não parece ser um destino considerável para embriões e impõe sua permanência. No impasse, os embriões permanecerão em tanques de nitrogênio até se tornarem um entulho, ou uma nova categoria que ajude e atribuir-lhe um novo destino como um "pós-embrião" ou um "não-embrião".

Todas essas concepções nos assinalam o quanto os embriões não são fixos e são frequentemente desestabilizados e negociados à luz de novas e velhas éticas. Fisicamente eles podem permanecer num tanque de nitrogênio em um canto qualquer de um pequeno laboratório, mas debates éticos como o que intentamos realizar aqui não se esgotam, permitem que esses embriões circulem e também seus significados.

\section{Referências}

ABREU, Domingos.

(2002). No Bico Da Cegonha: Histórias De Adoção e Adoção Internacional No Brasil. Rio De Janeiro, Relime Dumará.

ACERO, Liliana.

(2011). Governança Na Nova Genética E A Participação Pública: 0 Caso Das Pesquisas Com Células-Tronco. Physis 21 (3), p.795-812.

ALLEBRANDT, Débora.

(2013). Parenté Fluide: La Quête Des Origines $\mathrm{Au}$ Brésil Et Au Québec. Dialogue Entre Parenté, Droit Et Science. Université De Montréal. Disponível em: Http://Hdl.Handle. Net/1866/10210 .

(2009). Entre Movimento E Interdição: novas tecnologias reprodutivas conceptivas postas em prática. In: Ceres Karam Brum; Guilherme José da Silva e Sá (Orgs.); Entre poderes nativos e saberes ativos: antropologia e direitos humanos. Santa Cruz Do Sul, Edunisc.

(2007). Familia, Anonimato de Doadores e Adoção: diálogos e concepções. In: Débora Allebrandt and Juliana Lopes de Macedo; Fabricando A Vida: Implicações Éticas, Políticas e Sociais Sobre 0 Uso De Novas Tecnologias Reprodutivas. Porto Alegre, Metrópole.

ALLEBRANDT, Débora; MACED0, Juliana Lopes de (Orgs.).

(2007). Fabricando a vida: implicações éticas, políticas e sociais sobre o uso de novas tecnologias reprodutivas. Porto Alegre, Metrópole. 
BESTARDT, Joan.

(2012). Knowing And Relating: Kinship, Assisted Reproductive Technologies And The New Genetics. In: Jeanette Edwards; Carles Salazar (Eds.); European Kinship In The Age of Biotechnology. Berghahn Books.

\section{BHARADWAJ, Aditya.}

(2012). Enculturating cells: the anthropology, substance, and science of stem cells. Annual Review Of Anthropology .41 (1), p.303-317.

(2002). Conception Politics: Medical Egos, Media Spotlights, And The Constest Ober TestTube Firsts In India. In: Marcia C Inhorn and Frank Van Balen (Orgs.); Infertility around the globe. new thinking on childlessness, gender and reproductive technologies. Edited By, 315-333. Berkeley / Los Angeles / London, University Of California Press.

CARSTEN, Janet.

(2013). Introduction: Blood Will Out. Journal of The Royal Anthropological Institute, 19 (Suppl.1), p.1-23.

CESARINO, Letícia da Nóbrega.

(2007). Nas Fronteiras Do 'Humano': Os debates britânico e brasileiro sobre a pesquisa com embriões. Mana 13 (2), p.347-380.

COLLARD, Chantal; SHIREEN, Kashmeri.

(2011). Embryo adoption: emergent forms of siblingship among snowflakes $\AA$ families. American Ethnologist 38 (2); 307-322.

COOPER, Melinda; WALDY, Catherine.

(2014). Clinical labor tissue donors and research subjects in the global bioeconomy. Durham \& London, Duke University Press.

CORRÊA, Marilena Villela.

(2001). Novas tecnologias reprodutivas. Limites da Biologia ou Biologia sem limites? Rio de Janeiro, Eduerj.

COSTA, Rosely Gomes.

(2002). Sonho do passado versus plano para o futuro: gênero e representações acerca da esterilidade e do desejo por filhos. Cadernos Pagu, No. 17-18: 105-130.
(2001). Concepção de filhos, concepções de pais. Algumas reflexões sobre reprodução gênero. Tese de Doutorado apresentada ao Programa de pós-graduação em Ciências Sociais da Universidade Estadual de Campinas (UNICAMP).

DINIZ, Debora; AVELINO, Daniel.

(2009). Cenário internacional da pesquisa em células-tronco. Revista De Saúde Pública 43 (3), p.541-547.

FONSECA, Claudia.

(2012). Mães 'abandonantes': fragmentos de uma história silenciada. Revista Estudos Feministas 20 (1), p.13-32.

(2009). Abandono, adoção e anonimato: questões de moralidade materna suscitadas pelas propostas de 'parto anônimo. Sexualidad, Salud Y Sociedad, no. 1, p.30-62.

(1995). Caminhos da Adoção. Porto Alegre, Cortez Editora.

FRANKLIN, Sarah.

(2013). Biological relatives: ivf, stem cells and the future of kinship. Durham / London, Duke University Press.

GIBBON, Sahra; NOVAS, Carlos (Eds.).

(2008). Biosocialities, Genetics And The Social Sciences. New York, Routledge.

GRUDZINSKI, Roberta Reis.

(2009). Parentalidae e novas tecnologias reprodutivas: um estudo etnográfico sobre novas maneiras de conceber. Tese de Doutorado apresentada a Universidade Federal do Rio Grande do Sul (UFRGS).

JASANOFF, Sheila.

(2005). Designs on nature: science and democracy in Europe and The United States. Princeton, N.J.; Woodstock, Princeton University Press.

KLOTZ, Maren.

(2015). Wayward Relations: novel searches of the donor-conceived for genetic kinship. Medical Anthropology 9740 (January). 
LATOUR, Bruno.

(2004). Politics of nature: how to bring the sciences into democracy. Cambridge, Mass., Harvard University Press.

LUNA, Naara.

2005). Natureza humana criada em laboratório: biologização e genetização do parentesco nas novas tecnologias reprodutivas. Manguinhos 12 (2), p.395-417.

LUNA, Naara.

(2007). A personalização do embrião humano: da transcendência na Biologia. Mana 13 (2), p.411-440.

LUNA, Naara.

2012). Pesquisas com células-tronco: um estudo sobre a dinâmica de um segmento do campo cientifico. História, Ciências, Saúde Manguinhos 18 (1), p.49-70.

MANICA, Daniela Tonelli.

(2011). A desnaturalização da menstruação: hormônios contraceptivos e tecnociência. Horizontes Antropológicos, №. 35, p.197-226.

MANICA, Daniela Tonelli.

(2016). Cesam, as células do sangue menstrual: terapia celular, gênero e tecnociência. In $30^{a}$ Reunião Brasileira de Antropologia.

MELHUUS, Marit.

(2005). 'Better safe then sorry': legislating assisted conception in Norway. In: Christian Krohn-Hansen; Nusthad Knut; State Formation: Anthropological Perspectives.

MULKAY, Michael.

(1994). The triumph of the pre-embryo: interpretations of the human embryo in parliamentary debate over embryo research. Social Studies of Science 24 (4), p.611-639.

NASCIMENTO, Pedro Francisco Guedes. (2009). Reprodução, desigualdade e políticas públicas de saúde: uma etnografia da construção do 'desejo de filhos'. Tese de Doutorado apresentada ao Programa de Pós-graduação em Antropologia Social da Universidade Federal do Rio Grande Do Sul.
RAMIREZ-GÁLVEZ, Martha.

(2003). Novas tecnologias reprodutivas conceptivas: fabricando a vida, fabricando o futuro. Departamento de Ciências Sociais. Campinas, Universidade Estadual de Campinas.

RAMIREZ-GÁLVEZ, Martha.

(2011). Inscrito nos genes ou escrito nas estrelas? Adoção de crianças e uso de reprodução assistida. Revista de Antropologia 54 (1), p.47-87.

ROBERTS, Elizabeth F. S.

(2007). Extra embryos: the ethics of cryopreservation in ecuador and elsewhere. American Ethnologist 34 (1), p.181-199.

ROBERTS, Elizabeth F. S.

(2011). Abandonment and accumulation: embryonic futures in The United States and Ecuador. Medical Anthropology Quarterly 25 (2), p.232-253.

ROCA, Alejandra Rosario.

(2004). Fragmentos, fronteras y cuerpos incógnitos. Una mirada antropologica sobre la produccion y criopreservación de vida en laboratório. Tésis de Doctorado presentada a la Universidad de Buenos Aires (UBA).

ROCHA, Israel Jesus.

(2015). Quando humanos e não-humanos compõem uma audiência pública: o uso de embriões para produção de células-tronco embrionárias. Caderno Eletrônico de Ciências Sociais, 3 (1), p.133-155.

ROSE, Nikolas.

(2007). The politics of life itself: biomedicine, power, and subjectivity in the twenty-first century. Sociology of Health and Illness. Princeton, N.J., Princeton University Press.

SILVA, Susana; ALVES, Bruno Rodrigues; MACHAD0, Helena; SAMORINHA ,Catarina; FREITAS, Cláudia de.

(2016). Narrativas Em Torno Da Utilização De Embriões De Origem Humana Na Investigação Científica: Saúde, Ética E Cidadania. In: Claudia Fonseca; Fabíola Rohden; Paula Sandrine Machado; Heloísa Helena Salvatti Paim (Orgs.); Antropologia Da Ciência E Da 
Tecnologia: Dobras Reflexivas. Porto Alegre, Sulina.

STRATHERN, Marilyn.

(1992). Reproducing the future: essays on anthropology, kinship, and the new reproductive technologies. New York, Routledge.

TAMANINI, Marlene.

(2010). Os desafios e implicações éticas para a pesquisa produzidos pela disseminação das novas tecnologias no campo biomédico. In: Patrice Schuch; Miriam Steffen Vieira; Roberta Peters (Orgs.); Experiências, dilemas e desafios do fazer etnográfico contemporâneo. Porto Alegre, Editora da UFRGS.
THOMPSON, Charis.

(2014). Good science, bad science. Cambridge, MIT.

(2005). Making parents: the ontological choreography of reproductive technologies. Cambridge, Mass. / London, MIT.

\section{Recebido em}

outubro de 2017

Aprovado em março de 2018 